https://doi.org/10.17816/MAJ191S178-80

\title{
THE COMPARATIVE STUDY OF HUMAN ENDOGENOUS RETROVIRUS HERV-E $\lambda$ 4-1 EXPRESSION IN BLOOD IMMUNE CELLS OF MULTIPLE SCLEROSIS PATIENTS
}

\author{
I.A. Goldina ${ }^{1}$, E.V. Markova ${ }^{1,2}$ \\ ${ }^{1}$ Laboratory of Neuroimmunology, Federal State Budgetary Scientific Research Institute \\ of the Fundamental and Clinical Immunology, Novosibirsk, Russia; \\ ${ }^{2}$ Federal State Budgetary Educational Institution of Higher Professional Education \\ "Novosibirsk State Pedagogical University", Novosibirsk, Russia \\ СРАВНИТЕЛЬНОЕ ИССЛЕДОВАНИЕ ЭКСПРЕССИИ \\ ЭНДОГЕННОГО РЕТРОВИРУСА ЧЕЛОВЕКА \\ HЕRV-E $\lambda$ 4-1 В ИММУННЫХ КЛЕТКАХ КРОВИ БОЛЬНЫХ \\ РАССЕЯННЫМ СКЛЕРОЗОМ
}

\author{
И.А. Гольдина ${ }^{1}$, Е.В. Маркова ${ }^{1,2}$ \\ ${ }^{1}$ ФГБНУ «НИИ фундаментальной и клинической иммунологии», Новосибирск; \\ ${ }^{2}$ ФГБОУ ВПО «Новосибирский государственный педагогический университет», Новосибирск
}

In order to investigate the function of human endogenous retrovirus HERV-E $\lambda$ 4-1 in multiple sclerosis pathogenesis, the comparative research of frequency of this retrovirus expression and mRNA level on different types of blood immune cells of progredient course multiple sclerosis patients have been conducted with using of the reverse - transcriptase polymerase chain reaction method. Peripheral blood mononuclear cells were isolated on Ficoll density gradient centrifugations. Monocytes were separated by the adhesion to plastic Petri dishes. For the estimation of the mitogen-induced HERV-E $\lambda$ 4-1 expression, blood mononuclear cells were incubated with adding of phytogemagglutinin or pokeweed mitogen during 72 hours in $\mathrm{CO}_{2}$ incubator at $37^{\circ} \mathrm{C}$ and $5 \% \mathrm{CO}_{2}$. Results of HERV-E $\lambda$ 4-1 env gene expression estimation demonstrate that both monocytes and lymphocytes express HERV-E $\lambda$ 4-1. The level of the HERV-E $\lambda$ 4-1 env mRNA was higher in lymphocytes than in monocytes. The main source of HERV-E $\lambda$ 4-1 in progredient course MS patients between blood immune cells are lymphocytes, especially B lymphocytes.

Keywords: multiple sclerosis; endogenous retrovirus HERV-E $\lambda$ 4-1; immune cells.

С целью изучения функции эндогенного ретровируса человека HERV-E $\lambda$ 4-1 в патогенезе рассеянного склероза, проведено сравнительное исследование частоты его экспрессии и уровня мРНК в различных видах иммунных клеток крови больных рассеянным склерозом, прогредиентным типом течения заболевания, с использованием метода обратно-транскриптазной полимеразной цепной реакции. Мононуклеарные клетки периферической крови сепарировали центрифугированием на градиенте плотности Фиколла. Моноциты выделяли при помоши адгезии к пластиковым чашкам Петри. Для оценки митоген-индуцированной экспрессии HERV-E $\lambda$ 4-1, мононуклеарные клетки крови инкубировали с добавлением фитогемагглютинина или митогена лаконоса в течение 72 часов в $\mathrm{CO}_{2}$ инкубаторе при $37^{\circ} \mathrm{C}$ и $5 \% \mathrm{CO}_{2}$. Результаты оценки экспрессии гена env HERV-E $\lambda$ 4-1 продемонстрировали, что и моноциты, и лимфоциты экспрессируют данный вирус. Уровень экспрессии мPHK HERV-E $\lambda$ 4-1 env был выше в лимфоцитах, чем в моноцитах. Основным источником экспрессии HERV-E $\lambda$ 4-1 у больных рассеянным склерозом с прогредиентным типом течения заболевания являются лимфоциты, преимущественно, В лимфоциты.

Ключевые слова: рассеянный склероз; эндогенный ретровирус HERV-E $\lambda$ 4-1; клетки иммунной системы.

Introduction. Multiple sclerosis (MS) is a chronic inflammatory autoimmune disease of the central nervous system with neuro-immune mechanisms of pathogenesis. MS is the most widely spread among the human diseases characterized by the myelin destruction. Until now both the etiology and pathogenesis of MC have to a large extent remained unclear. Complex interaction between genetic predisposition and environmental risk factors determines the development of MS as a polyetiological immune-mediated disease. Degenerative and inflammatory changes in the nervous tissue in MS are characterized by a multiple fibrosis of neuron myelin sheath accompanied by the formation of sclerotic plaques and axon pathology resulting in progressive neurological dysfunction [1]. Human endogenous retroviruses (HERVs) represent the major part of long terminal repeat (LTR) retrotransposons and constitute about $8 \%$ of the genome [2]. Some immunotropic HERVs are considered to be the most significant factors in the etiology and pathogenesis of MS [3]. Canonically a full-length HERV provirus sequence consists of an internal region of four basic retroviral genes ( $\mathrm{gag}$, pol, pro, $e n v$ ), flanked by two LTRs, which are identical at the time of integration and are essential for replication [4]. The accumulation of the post-insertional mutations, stop-codons and deletions caused in the 
majority of HERVs a lack of an extracellular phase of development, rendering them noninfectious. Nevertheless, some HERVs have open reading frames encoding functional viral proteins in $e n v$ region and are able to transcribe [5]. HERV-E $\lambda$ 4-1 is associated with some autoimmune diseases, may activate and produce some proteins with immunotropic properties [6]. In order to investigate the function of human endogenous retrovirus HERV-E $\lambda$ 4-1 in multiple sclerosis pathogenesis, the comparative research of the frequency of expression and the level of mRNA of endogenous retrovirus HERV-E $\lambda$ 4-1 on different types of blood immune cells of patients with progredient course of multiple sclerosis was the aim of this study.

Material and methods. Peripheral blood mononuclear (BMC) cells were isolated by the Ficoll density gradient $1.077 \mathrm{~g} / \mathrm{ml}$ centrifugation of venous blood. Monocytes were separated by the adhesion to plastic Petri dishes after the incubation in supplemented HEPES - buffered RPMI - 1640. For the estimation of the mitogen-induced HERV-E $\lambda$ 4-1 expression BMC were incubated in supplemented RPMI - 1640 with phytogemagglutinin (PHA) of pokeweed mitogen (PWM) during 72 hours in $\mathrm{CO}_{2}$ incubator at $37^{\circ} \mathrm{C}$ and $5 \% \mathrm{CO}_{2}$. Examination of gene expression of env HERV-E $\lambda$ 4-1 has been conducted by the method of reverse - transcriptase polymerase chain reaction. Isolation of the total RNA was performed by the method of phenol extraction, with using of the VectoRNA - extraction test-system (Vector - Best, Novosibirsk). The obtained DNA was amplified in a "Terzik" programmable amplifiers, (DNA technology, Moscow), using the oligonucleotide primer pairs for the env HERV-E $\lambda$ 4-1 gene. The obtained cDNA fragments were analyzed in $2 \%$ agarose gel with the addition of $0.00001 \%$ bromide ethidium (VectoDNA - EF, Vector Best, Novosibirsk). Samples with a cDNA band in the gel corresponding to the expected amplicon size were considered as positive. The morphological analysis of the peripheral blood cells conducted by the hematoxylin and eosin staining. Statistical data processing was performed by using the STATISTICA v.10.0 software package (StatSoft, USA). The statistical significance of the differences was estimated by the Kruskall-Wallis criterium at $p<0.05$.

Results and discussion. It was found that the frequency of env gene HERV-E $\lambda$ 4-1 expression in non-separated $\mathrm{BMC}$ of patients with progredient course of MS reaches to $64.2 \%$ (43/67 patients), it far exceeds the level in BMC of healthy volunteers $(2.5 \%, 1 / 40$ individuals) and patients with central nervous system chronic degenerative nonprogressive diseases $(4.5 \%, 2 / 44$ patients, $p<0.05)$. After the separation of the cells and morphological examination it was established that the majority of adhesive cells were monocytes, and the non-adhesive were lymphocytes. Results of the estimation of HERV-E $\lambda$ 4-1 env gene expression in MS patients with progredient course of disease demonstrate that both monocytes and lymphocytes express HERV-E $\lambda$ 4-1 env gene. At the same time, the level of the HERV-E $\lambda$ 4-1 env mRNA was higher in unstimulated lymphocytes than in monocytes ( $246 \mathrm{u} / \mathrm{od}$ and $74 \mathrm{u} / \mathrm{od}$, respectively, $p<0.05$ ). In mitogen-stimulated cultures of MS patient's lymphocytes the HERV-E $\lambda$ 4-1 env gene expression was higher in those, stimulated with PWM, enriched with B-lymphocytes, then PHA-stimulated $(356 \mathrm{u} / \mathrm{od}$ and $282 \mathrm{u} / \mathrm{od}$, respectively, $p<0.05)$. So, the main source of HERV-E $\lambda$ 4-1 in patients with progredient course of MS between blood immune cells are lymphocytes, especially cultures, enriched by mitogen stimulation with B-lymphocytes. As lymphocytes of progredient course of MS patients are characterized by the higher proliferative activity in comparison with those of central nervous system chronic degenerative non-progressive diseases patients [3,7], the higher degree of activation of the HERV-E $\lambda$ 4-1 is behavioral for active proliferating peripheral blood lymphocytes of patients with progredient course of MS, especially for B-lymphocytes.

\section{References}

1. Goldina IA, Markova EV. Neiroimmunnye mehanismy patogeneza rasseyannogo sclerosa. Krasnoyarsk: Nauchno-innovacionnyi centr; 2018. 150 p. (In Russ.). https://doi.org/10.12731/978-5-906314-89-5.

2. Lander ES, Linton IM, Birren B, et al. Initial sequencing and analysis of the human genome. Nature. 2001;409:860-921. https://doi.org/10.1038/35057062.

3. Smagin AA, Goldina IA, Gaidul KV. Issledovanie proliferativnoi aktivnosti mononuclearnyh kletok krovi bolnyh rasseyannym sklerozom pri vozdeistvii peptide regiona envelope endogennogo retrovirusa cheloveka HERV-E $\lambda$ 4-1. Medicinskaya immunologia. 2014;16(3):247-256. (In Russ.).

4. Vargu L, Rodrigues-Tome P, Sperber GO, et al. Classification and characterization of human endogenous retroviruses; mosaic forms are common. Retrovirology. 2016;13:7. https://doi.org/10.1186/s12977-015-0232-y.

5. Laufer G, Mayer J, Mueller BF, et al. Analysis of transcribed human endogenous retrovirus W env loci clarifies the origin of multiple-sclerosis associated retrovirus env sequences. Retrovirology. 2009;6:37. https:// doi.org/10.1186/1742-4690-6-37.

6. Goldina IA, Gaidul KV, Kozlov VA. UFO-inducyrovannaia ekspressia endogennogo retrovirusa cheloveka HERV-E $\lambda$ 4-1 v mononuclearnyh kletkah krovi. Bulleten sibirskoi mediciny. 2018;17(1):36-44. (In Russ.). https://doi.org/10.20538/1682-0363-2018-1-36-44.

7. Goldina IA, Safronova IV, Goldin BG, Gaidul KV. Pattern of relationship of the level of mRNA of human endogenous retrovirus of class I L 4-1 envelope gene and proliferative activity of blood mononuclear cells. International Immunology. 2010;22(S1):i71. 